\title{
LANDSLIDE HAZARD ASSESSMENT APPROACH ON THE PROVINCIAL ROAD IN EAST JAVA
}

\author{
Emil Wahyudianto ${ }^{1}$, \\ ${ }^{1}$ Road and Bridge Engineering, East Java Provincial Road and Bridge Public Works Office, \\ Gayung Kebonsari 167 Surabaya, Indonesia \\ e-mail: emilwahyudianto@gmail.com
}

\begin{abstract}
Landslide hazard mapping on the road infrastructure has 2 (two) main sources. The first is through a landslide inventory survey, and the second is through recording data on past landslide events. Each of the methods above has advantages and disadvantages. The most appropriate moment in making a landslide hazard map is when a certain disaster strikes an area with a certain measured impact. The Unpredictable variables that have been hidden and difficult to predict will be eliminated. Disaster events in disaster-prone mapping become a key variable as well as a validator. The characteristic of the landslide on road is also very specific, depends on the nature of the vehicle's spatial movement, and the scope of the affected area which is narrow but extends along the slopes coincide with the road. The most appropriate disaster mapping in measuring the level of hazard, vulnerability, and risk on the road is based on landslide record data. That is because the variables used to predict landslide events are extremely varied and too many are unknown. Assessing a map using a landslide disaster occurrence on the road is easier than making a map through the calculation method of certain variables that are overlapped. Based on the calculation of frequency analysis for 12 years, the daily rainfall value of $126.2 \mathrm{~mm}$ per day is the threshold of rain which has a probability of a landslide of $95 \%$ on the road infrastructure in East Java Province.
\end{abstract}

Keywords: validating landslide; landslide on roads; landslide assessment; landslide inventory.

\section{Introduction}

Classification of mass movement according to Hungr et al. [1] which is adopted from Hutchison [2], modified Cruden and Varnes [3] of the classification of Varnes [4] outline landslides based on the direction of movement and the type of the material. The movement of slope material on a road is generally a rock fall or tipping, material collapse from the upside slope, or it can also be subsidence on the road body. The type of landslide originating from the upside slope is generally fast, without signs, often controlled by the cumulative daily rainfall, and the dimensions of the landslide material are small. For rocky slopes, the properties of slope failure are generally dominated on rock slopes with fractures, or joints [5].

In analyzing the risk of vehicle movement against landslides [6], Pierson \& van Vickle [7] adopted by Guzzetti [8], and Parise [9], formulated vehicle movement vulnerability based on the spatial probability of vehicle existence on a road segment. The approach to calculating the risk of falling rocks is standardized by AGS [10] in Australia. The rock slopes with relatively small cracks/ low level of weathering, the slope failure pattern is more of a sliding, rock block, falling and topple. Whereas for rock slopes with a joint set/ high level of weathering, the slope collapse that occurs is generally in the form of rock-weathered flow and rock slump. This weathered flow is triggered by the failure of the frictional bonds in the crack gap as a result of water flow during rain. Particularly in certain cases, mass movement has a broad impact. The movement of this mass is more controlled by the groundwater level than by the influence of certain periods of rain. Another characteristic of 
this mass movement is that it has a slow rate of movement, has an affected area of $>2.5$ ha, and has a deep enough slip area (more than 6 meter). The movement of this density (landslide) must go through a complex investigation involving geological disciplines for the interpretation of rock and soil properties in the landslide zone.

Wahyudianto [6] state that the characteristics of mass movement along road segments occur in road segments that experience slope cuts. Of the 34 (thirty-four) landslide points studied by Purnomo [11] at the Arjuno Quaternary Volcano Complex, 64\% were identified as being on a slope or road. Meanwhile, Wahyudianto [6] who examined landslides on the Batu-Kediri road section stated that $85 \%$ of the 92 landslide points compiled between 2008-2016 occurred in the slope cutting zone.

A landslide inventory survey is a survey conducted to identify mass movements at the research location. Generally, this survey is a preliminary field-based survey to inventory landslide locations, impacts, types, magnitudes, characteristics of supporting variables, and other parameters that affect landslide events. Landslide inventory surveys on roads are absolutely field-based considering the need for a high level of accuracy. The results of this survey are used as a reference for further handling in order to reduce disaster risk. Generally, the symptoms of mass movement on a slope can be easily identified through a landslide inventory survey.

Apart from using a landslide inventory survey, efforts to mitigate the hazard of slope collapse on the road can be done through historical data analysis of past landslides. The landslide record data can be used to predict and describe events. In an agency with the ability to compile a good landslide database, landslide event data can be used to predict future landslide behavior based on historical event data. The landslide event data record combined with time-based rainfall data can be used to find a causal relationship between landslide and the rain. The two types of approaches above, namely landslide inventory surveys and landslide event record data. Each oh both methods have their strengths and weaknesses. If the landslide inventory survey is weak in providing an overview of actual events, the landslide event record data has limited accuracy and objectivity in reporting because it comes from many sources of information.

\section{Landslide Assessment On Road}

Wahyudianto [5] used the Cempaka cyclone event as a validator for mapping landslides along the affected roads (provincial roads in Pacitan Regency). By using the actual data variable for landslide positions on the road section, Wahyudianto [5] divided the landslide data that was obtained into 2 (two) parts, namely data on the location of the incident, and data on landslide types based on the type of material. By using the Cempaka cyclone event in 2017 where the daily rainfall data reached $447 \mathrm{~mm} /$ day (Ringin Harjo Station), the landslide distribution data that was successfully identified in the field is as shown in Figure 1. The landslide hazard map as in Figure 1 has high accuracy because it is through a natural cyclone storm validator.

Wahyudianto [6] had also identified the level of landslide risk on the Batu-Kediri road section using actual data on landslides. The data was collected through a series of landslide inventory surveys, resulting in the Landslide Hazard Assessment (LHA) map as shown in Figure 2. The difference is if the Cempaka Cyclone event which becomes a validator on the provincial road in Pacitan district occurs in one day. Meanwhile, the data used in the landslide risk assessment of the Batu-Kediri section were collected through a combination of 2 (two) data, namely secondary data in the form of historical records of landslides, and landslide inventory surveys in the field.

Landslide hazard assessment using high impact disaster validators (such as landslides due to Cempaka cyclones) has a higher level of accuracy than through landslide inventory surveys under normal conditions. This is because the landslide traces on the mapped road are more than 2 (two) weeks after the incident occurred, failing to record important features that are used for further assessment.

\subsection{Landslide Characteristics on Provincial road in East Java}

There are four most important rainy months which contributed a lot to landslide on roads. The months are December, January, February and March. Wahyudianto [5] calculated that these months 
contributed to $93.04 \%$ of occurrence. While the results of the renewal process by Wahyudianto [12], these months contributed as much $91.87 \%$ occurrences as listed in Table 1 and Figure 4. The distribution of landslide events on a yearly basis, most of the disaster events occurred in 2013 and 2014 or amounted to $49.59 \%$ as listed in Table 3. The slope movement data that has been recorded from 2007 until June 2020 is 93 sources, with details of the occurrence is 78 days and 123 points location. The slightly change of the slope movement occurrence is assumed as the function of the change of rainy season and rainfall distribution during the month.

\subsection{The threshold value for rain that causes landslides}

Rainfall threshold that results in landslides can be used as a reference when an extreme rain event is considered as a representative time for conducting post-disaster landslide inventory surveys. Wahyudianto proposes the value of daily rain, $\mathrm{P}_{0}>190 \mathrm{~mm}$ with the cumulative rainfall of the previous 3 days, $P_{3}$ of $>180$. This value is a record of a fairly massive disaster on January 31, 2014 on the Batu-Kediri road network. From the analysis of the threshold for landslide-triggering rain, the rain parameter value on January 31, 2014 is far above the $95 \%$ probability value of landslide triggering rain based on disaster event record data between 2007-2016 of the road segments.

\section{Result and Discussion}

Landslide hazard assessment on the provincial roads in East Java has 2 (two) sources. The first is through a landslide inventory survey, and the second is through recording data on past landslide events. Each of the methods above has advantages and disadvantages. The most appropriate moment in making a landslide hazard map is when a disaster strikes an area. Variables of uncertainty that have been hidden and difficult to predict will be eliminated. Disaster events in disaster-prone mapping become a key variable as well as a validator. In the case of Cempaka Cyclones, landslides that occur in the affected zone are both a validator and a determining factor for the results.

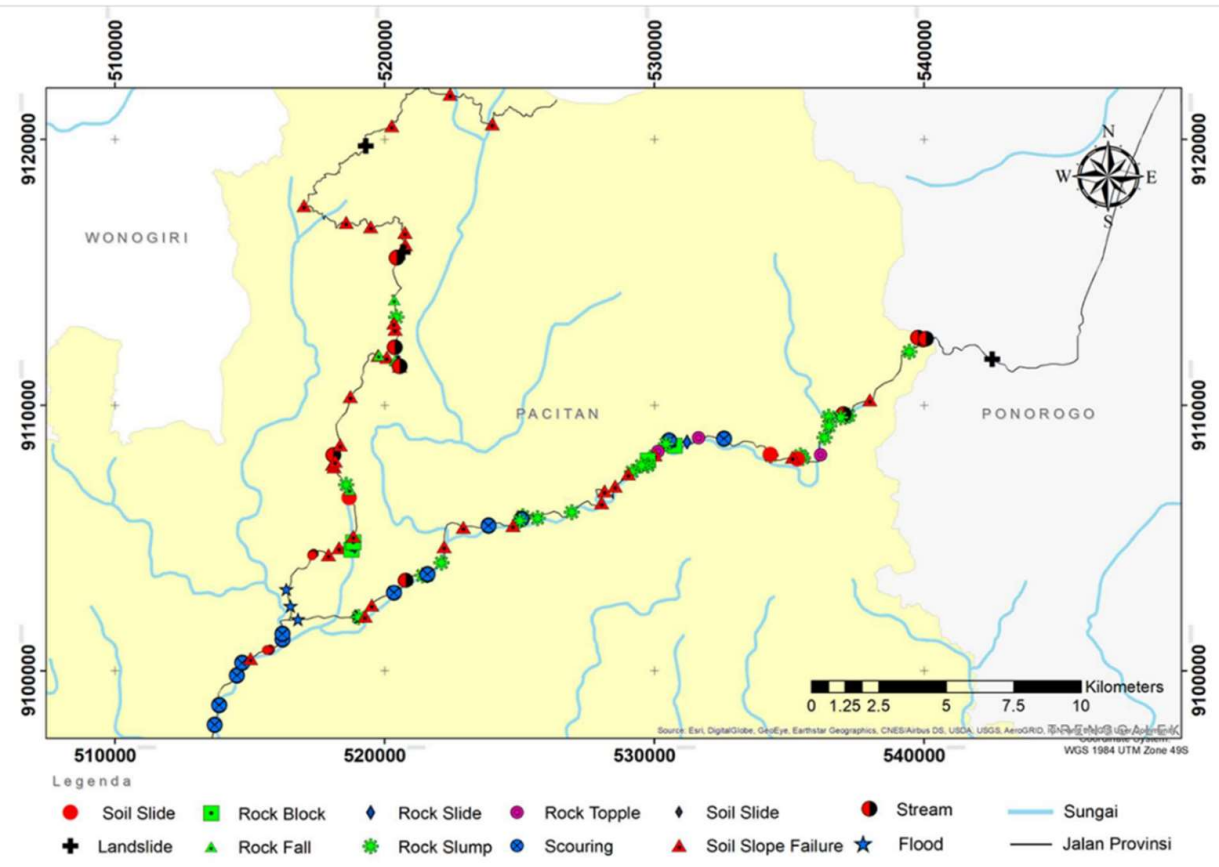

Figure 1. Landslide point for provincial road in Pacitan regency due to Cempaka Cyclone (November, 2017) based on the type of landslide material 


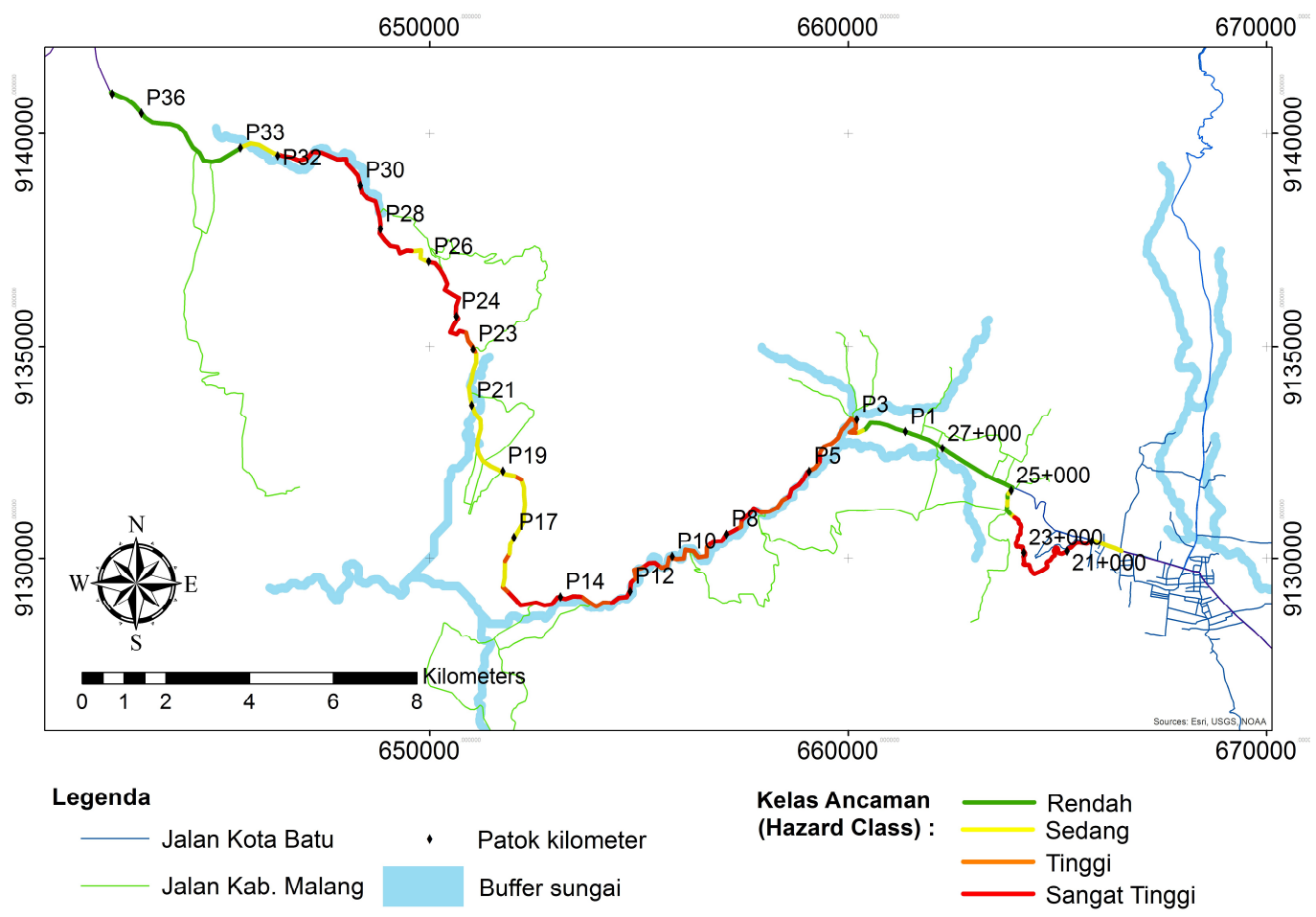

Figure 2. Landslide Hazard Assessment (LHA) map on Batu-Kediri road network (2017).

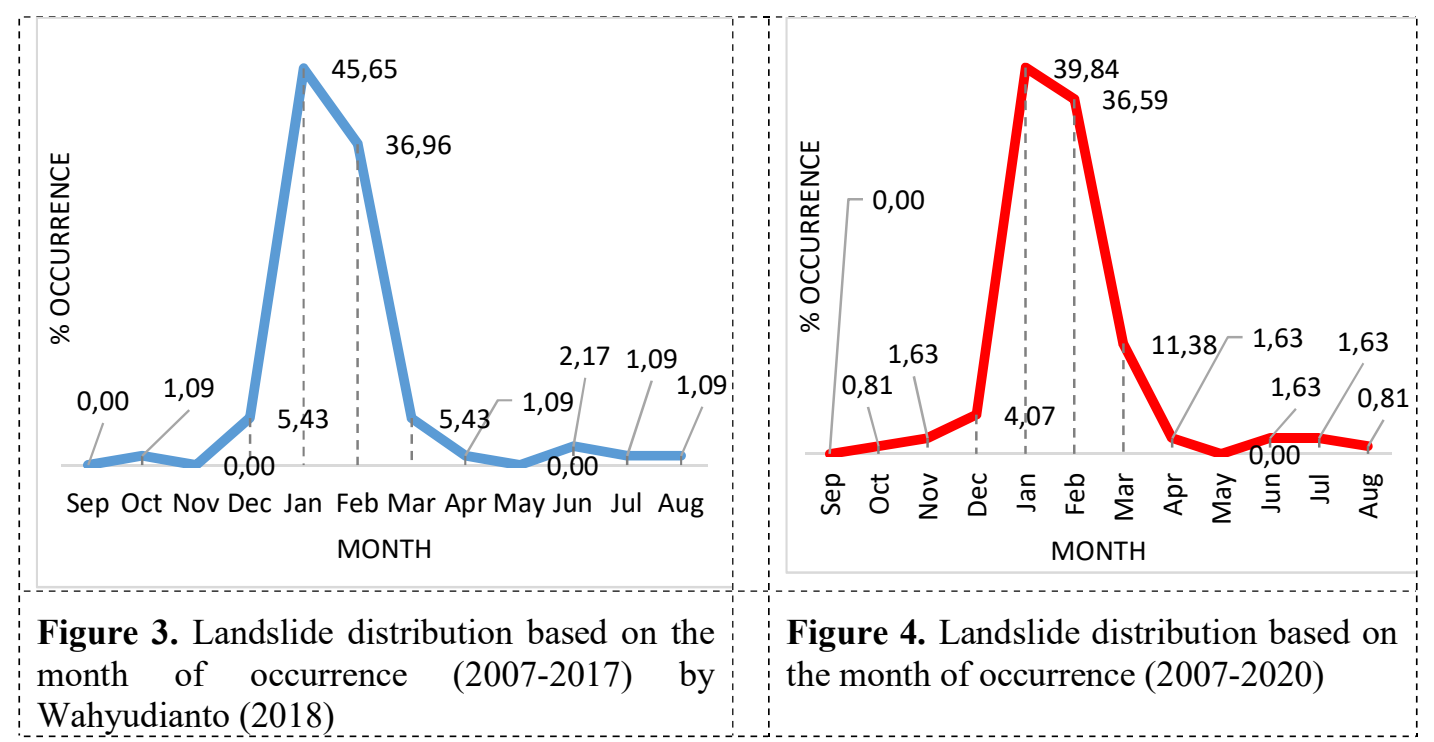


Table 1. Distribution of slope movement on the Batu-Kediri road network during

\begin{tabular}{cccccc} 
No & Month & $\begin{array}{c}\text { D, days of } \\
\text { Occurence }\end{array}$ & $\begin{array}{c}\text { n, number of } \\
\text { landslide } \\
\text { points }\end{array}$ & $\% \mathrm{D}$ & $\% \mathrm{n}$ \\
\hline 1 & Jan & 24 & 49 & 30.77 & 39.84 \\
\hline 2 & Feb & 27 & 45 & 34.62 & 36.59 \\
\hline 3 & Mar & 13 & 14 & 16.67 & 11.38 \\
\hline 4 & Apr & 2 & 2 & 2.56 & 1.63 \\
\hline 5 & May & 0 & 0 & 0.00 & 0.00 \\
\hline 6 & Jun & 1 & 2 & 1.28 & 1.63 \\
\hline 7 & Jul & 2 & 2 & 2.56 & 1.63 \\
\hline 8 & Aug & 1 & 1 & 1.28 & 0.81 \\
\hline 9 & Sep & 0 & 0 & 0.00 & 0.00 \\
\hline 10 & Oct & 1 & 1 & 1.28 & 0.81 \\
\hline 11 & Nov & 2 & 2 & 2.56 & 1.63 \\
\hline 12 & Dec & 5 & 5 & 6.41 & 4.07 \\
\hline & $\Sigma$ & 78 & 123 & 100.00 & 100.00 \\
\hline
\end{tabular}

Table 2. Distribution of slope movements by sub-district during 2007-2020

\begin{tabular}{cccccc}
\hline Sub-district & Batu & Pujon & Ngantang & $\begin{array}{c}\text { Kasembo } \\
\mathrm{n}\end{array}$ & $\Sigma$ Sun \\
\hline $\begin{array}{c}\text { n, number of landslide } \\
\text { occurrence }\end{array}$ & 45 & 48 & 14 & 16 & 123 \\
\hline $\mathrm{n}(\%)$ & $37 \%$ & $39 \%$ & $11 \%$ & $13 \%$ & $100 \%$ \\
\hline n per year & 3.46 & 4.36 & 1.27 & 1.45 & 11.18 \\
\hline Lenght, L $(\mathrm{km})$ & 4.53 & 13.97 & 15.34 & 10.94 & 44.78 \\
\hline $\mathrm{n} / \mathrm{L}$, density $(\mathrm{n} / \mathrm{km})$ & 9.93 & 3.44 & 0.91 & 1.46 & 2.75 \\
\hline
\end{tabular}

Table 3. Distribution of slope movements by year of occurrence during 20072020

\begin{tabular}{ccc}
\hline Year & $\begin{array}{c}\text { D, day of } \\
\text { occurrence }\end{array}$ & $\begin{array}{c}\text { n, number of } \\
\text { occurrence }\end{array}$ \\
\hline 2020 , Jan- June & 5 & 5 \\
\hline 2019 & 5 & 5 \\
\hline 2018 & 9 & 11 \\
\hline 2017 & 9 & 10 \\
\hline 2016 & 10 & 12 \\
\hline 2015 & 2 & 2 \\
\hline 2014 & 11 & 35 \\
\hline 2013 & 16 & 26 \\
\hline 2012 & 4 & 4 \\
\hline 2011 & 2 & 5 \\
\hline 2010 & 3 & 6 \\
\hline 2009 & 0 & 0 \\
\hline 2008 & 1 & 1 \\
\hline 2007 & 1 & 1 \\
\hline$\Sigma$ & 78 & 123
\end{tabular}




\section{Conclusions}

The limitation of structural-based risk reduction capability means that this risk remains and will continue to recur when the threshold for disaster events is exceeded. To reduce the risk of landslides for road users, non-structural measures such as more detailed mapping of the vulnerability of cliffs are required, determination of the threshold for landslide triggers based on historical data records, which will be followed by building an early warning system for landslide risk alarms on high-risk road segments.

\section{Acknowledgements}

Special thanks to the Road and Bridge Office, East Java Province, for the permission and opportunity given in conducting the research.

\section{References}

[1] O. Hungr, S. G. Evans, M. J. Bovis, and J. N. Hutchinson, "A review of the classification of landslides of the flow type," Environ. Eng. Geosci., 2001, doi: 10.2113/gseegeosci.7.3.221.

[2] J. N. Hutchinson, "General report: morphological and geotechnical parameters of landslides in relation to geology and hydrogeology," Landslides. Proc. 5th Symp. Lausanne, 1988. Vol. 1, 1988, doi: 10.1016/0148-9062(89)90310-0.

[3] D. M. Cruden and D. J. Varnes, "Landslides Types and Processes," 1996.

[4] D. Varnes, "SLOPE MOVEMENT TYPES AND PROCESSES," Spec. Rep., 1978.

[5] E. Wahyudianto, "INVENTARISASI BAHAYA LONGSOR JALAN PADA FASE PASCA BENCANA (STUDI KASUS SIKLON CEMPAKA) PADA JALAN PROVINSI DI KABUPATEN PACITAN," in PROSIDING KONFERENSI NASIONAL TEKNIK JALAN (KNTJ) KE-14 Pembangunan Infrastruktur Jalan dalam Era Teknologi Industri 4.0, 2019, pp. 503-518, [Online]. Available: https://fdokumen.com/document/konferensi-nasionalteknik-jalan-ke-10-ii-prosiding-konferensi-nasional-teknik-jalan.html.

[6] E. Wahyudianto, "Analysis and Risk Study on Landslide Hazard Frequency at Road Corridor of Batu City - Kediri Regency Border," J. Civ. Eng. Forum, 2018, doi: 10.22146/jcef.37446.

[7] L. A. Pierson and R. Van Vickle, "Rockfall Hazard Rating System - Participant's Manual," FHWA Sa-93-057, 1993.

[8] F. Guzzetti, "Landslide hazard assessment and risk evaluation: limits and prospectives," 2003.

[9] M. Parise, "Landslide hazard zonation of slopes susceptible to rock falls and topples," Nat. Hazards Earth Syst. Sci., 2002, doi: 10.5194/nhess-2-37-2002.

[10] "Landslide risk management concepts and guidelines," Australian Geomechanics Journal. 2000.

[11] P. N. H, Sutikno, and M. L, "Risiko Longsor Lahan Pada Lahan Pertanian Di Kompleks Gunungapi Kuarter Arjuno Jawa Timur," Universitas Gadjah Mada, 2010.

[12] E. Wahyudianto, "Updating the slope-movement data on the Batu-Kediri road network using digital information," 2020, doi: 10.1088/1757-899X/930/1/012031. 